\title{
Experimental comparison of thermal conditions in office rooms: diffuse ceiling ventilation, chilled beam system and chilled ceiling combined with mixing ventilation
}

Lestinen, Sami; Mustakallio, Panu; Kilpeläinen, Simo; Kosonen, Risto; Jokisalo, Juha; Koskela, Hannu; Melikov, Arsen Krikor

Published in:

Science and Technology for the Built Environment

Link to article, DOI:

$10.1080 / 23744731.2019 .1708210$

Publication date:

2020

Document Version

Peer reviewed version

Link back to DTU Orbit

Citation (APA):

Lestinen, S., Mustakallio, P., Kilpeläinen, S., Kosonen, R., Jokisalo, J., Koskela, H., \& Melikov, A. K. (2020). Experimental comparison of thermal conditions in office rooms: diffuse ceiling ventilation, chilled beam system and chilled ceiling combined with mixing ventilation. Science and Technology for the Built Environment, 26(5), 631-642. https://doi.org/10.1080/23744731.2019.1708210

\section{General rights}

Copyright and moral rights for the publications made accessible in the public portal are retained by the authors and/or other copyright owners and it is a condition of accessing publications that users recognise and abide by the legal requirements associated with these rights.

- Users may download and print one copy of any publication from the public portal for the purpose of private study or research.

- You may not further distribute the material or use it for any profit-making activity or commercial gain

- You may freely distribute the URL identifying the publication in the public portal 


\section{A Aatto University}

This is an electronic reprint of the original article.

This reprint may differ from the original in pagination and typographic detail.

Lestinen, Sami; Mustakallio, Panu; Kilpeläinen, Simo; Kosonen, Risto; Jokisalo, Juha;

Koskela, Hannu; Melikov, Arsen Krikor

Experimental comparison of thermal conditions in office rooms: diffuse ceiling ventilation, chilled beam system, and chilled ceiling combined with mixing ventilation

Published in:

Science and Technology for the Built Environment

DOI:

$10.1080 / 23744731.2019 .1708210$

Published: 27/05/2020

Document Version

Peer reviewed version

Please cite the original version:

Lestinen, S., Mustakallio, P., Kilpeläinen, S., Kosonen, R., Jokisalo, J., Koskela, H., \& Melikov, A. K. (2020).

Experimental comparison of thermal conditions in office rooms: diffuse ceiling ventilation, chilled beam system, and chilled ceiling combined with mixing ventilation. Science and Technology for the Built Environment, 26(5), 631-642. https://doi.org/10.1080/23744731.2019.1708210

This material is protected by copyright and other intellectual property rights, and duplication or sale of all or part of any of the repository collections is not permitted, except that material may be duplicated by you for your research use or educational purposes in electronic or print form. You must obtain permission for any other use. Electronic or print copies may not be offered, whether for sale or otherwise to anyone who is not an authorised user. 


\title{
Original research article
}

for Science and Technology for the Built Environment, Taylor \& Francis

\section{Experimental comparison of thermal conditions in office rooms: diffuse ceiling ventilation, chilled beam system and chilled ceiling combined with mixing ventilation}

\author{
Sami Lestinen ${ }^{1}$, Panu Mustakallio ${ }^{2}$, Simo Kilpeläinen ${ }^{1}$, Risto Kosonen ${ }^{1,5}$, Juha Jokisalo ${ }^{1}$, \\ Hannu Koskela ${ }^{3}$, Arsen K. Melikov ${ }^{4}$ \\ ${ }^{1}$ Department of Mechanical Engineering, Aalto University, Espoo, Finland \\ ${ }^{2}$ Halton Oy, Haltonintie 1-3, 47400 Kausala, Finland \\ ${ }^{3}$ Turku University of Applied Sciences, Turku, Finland \\ 4 .International Centre for Indoor Environment and Energy, Technical University of Denmark, Lyngby, Denmark \\ ${ }^{5}$ College of Urban Construction, Nanjing Tech University, China
}

\begin{abstract}
Thermal environments generated by diffuse ceiling ventilation (DCV), chilled beam (CB) and chilled ceiling with mixing ventilation (CCMV) systems were compared at different heat gains. Experiments were carried out in two test chambers, in which a double office layout was investigated near heated windows. The heat gain strength was increased from a normal level of 37-40 W/floor- $m^{2}$ to a peak load level of 57-64 W/floor$m^{2}$ to observe effects on indoor air thermal conditions and draft discomfort. The target indoor air temperature was $26 \pm 0.5^{\circ} \mathrm{C}$ in the occupied zone. The results show that the air temperature, air speed and draft risk levels were reasonable at the normal load and increased slightly at the peak load conditions. The CCMV system provided the smallest share of locations, in which the draft risk level was higher than $10 \%$. None of the studied systems achieved the category A defined by EN ISO 7730. However, all the systems fulfilled the demands of category $B$, except for $C B$ which felt to category $C$ at the peak load conditions by exceeding the draft risk limit in one location. Thermal conditions were at a same level with the studied systems. However, CCMV may reduce slightly the draft discomfort.
\end{abstract}

Keywords: office, air distribution, convective system, radiant system, draft 


\section{Introduction}

Indoor thermal conditions and comfort are important factors of human well-being. For instances, ASHRAE 55, EN ISO 7730 and EN 15251 standards recommend the acceptable parameters on thermal comfort (ASHRAE 2017; CEN 2005; CEN 2007). Furthermore, earlier studies have shown that occupants have ranked thermal comfort to be more important factor than the visual comfort, acoustic comfort or even a good indoor air quality (Frontczak and Wargocki 2011). Dissatisfaction with one factor does not necessarily leads to a dissatisfaction with overall comfort (Humphreys 2005). For instances, Arens et al. (2006) have proposed that an overall thermal sensation follows the warmest sensation at head and the coldest sensation of hands and feet in the warm and the cool environments, respectively. Therefore, it is important to explore thermal discomfort locally. However, occupants are usually more sensitive to a local thermal discomfort when the whole body is cooler than neutral and less sensitive to a local thermal discomfort when the whole body is warmer than neutral (ASHRAE 2017). The thermal discomfort can be assessed e.g. by conducting a local draft risk model, which predicts a local discomfort due to draft as a percentage of people dissatisfied (Fanger 1970; Fanger et al. 1988; CEN 2005; ASHRAE 2017). Earlier, thermal comfort has been investigated in the large web-based survey in the USA, Canada and Europe (Zagreus et al. 2004; Frontczak et al. 2012). The authors found that an average office building occupant is usually rather satisfied with a workstation environment. Regardless of that, thermal discomfort has been a common complaint indoors (Melikov et al. 2005; Kosonen et al. 2011; Taleghani et al. 2013).

Thermal discomfort can have many implications on occupants. Melikov and Kaczmarczyk (2012) showed how the indoor air movement improves an acceptability on perceived air quality and freshness of indoor air. The authors found that air movement reduces a negative impact of increased indoor air temperature, relative humidity and pollution level. However, a draft risk may increase when the additional air is supplied to the occupants (Melikov et al., 2002; Melikov et al., 2007a). In a subsequent study, Melikov (2016) emphasized that the advanced air distribution methods can improve thermal comfort and energy efficiency. Fang et al. (2004) proposed that the perception of air freshness and acceptability can be improved when inhaled air temperature and humidity decrease. Wargocki and Wyon (2007) found that reducing room 
air temperature improves the performance of schoolwork and Lan et al. (2011) stated that the health symptoms and performance get worse when the occupants feel thermally warm. Kosonen and Tan (2004) explained that the productivity loss is significant at the higher indoor air temperature compared to the neutral thermal perception. Those studies greatly justify an importance of discovering the thermal conditions and draft risk in office environments.

Ventilation is an important factor on thermal and healthy indoor environment (Müller et al. 2013; Yang et al., 2019). Generally, the main challenge in air distribution is to provide occupants with clean air for breathing and maintain their thermal comfort. The ventilation also dilutes indoor air and extracts contaminants (Mundt et al. 2004; Sandberg et al. 2019). Seppänen et al. (1999) stated that ventilation rates below $10 \mathrm{~L} / \mathrm{s}$ per person can be associated with a statistically significant decline in health or perceived air quality outcomes. Altogether, ventilation and indoor climate have been shown to affect significantly on learning and human performance (Wargocki et al., 2002; Wargocki and Wyon, 2007; HaverinenShaughnessy et al. 2011; Maula et al., 2017; Carrer et al., 2018). Therefore, ventilation and convective cooling methods are necessary for indoor environments.

Diffuse ceiling ventilation is a convective cooling method, in which an even supply of perforated suspended ceiling penetrates supply air down to the occupied zone instead of local supply openings (Nielsen 2011; Zhang et al. 2014; Zhang et al. 2016; Zhang et al. 2017). It may improve thermal comfort and reduce the draft risk (Jacobs et al. 2008; Jacobs and Knoll 2009; Fan et al. 2013). However, the heat gain strength, the heat gain distribution and the room height may affect the ventilation performance (Nielsen et al. 2015; Nielsen et al. 2017). The findings also indicate that the highest cooling capacity can be reached while the perforated panels cover the entire ceiling and the heat sources are distributed evenly (Rahnama et al. 2019). In addition, the diffuse ceiling ventilation has been found to perform well in the transient conditions (Kristensen et al. 2017). Furthermore, a recent review concluded that the diffuse ceiling ventilation may handle high heat gains without increasing the risk on thermal discomfort (Wu et al. 2018b). The authors emphasized that the system can have an energy saving potential due to a low-pressure drop through the diffuse ceiling.

Thermal radiation asymmetry affects the thermal comfort (Fanger et al. 1985). Consequently, a ventilation rate can be reduced by using a radiant system at high heat gain levels. In this way, the indoor air 
temperature can also be kept at a higher level than without a radiant system (Le Dréau and Heiselberg 2014). However, a local radiant cooling on a face may improve an acceptability on perceived air quality, but not as much as a convective cooling by raising the air velocity (Melikov et al. 2013b). Furthermore, the combined air and water system may require more adjusted design and control strategy compared to all air system (Saber et al. 2016). An important matter is also to keep the water inlet temperature higher than the surrounding indoor air dew point to prevent a condensation on cold surfaces (Kosonen and Tan 2005; Rhee and Kim 2015). Generally, a radiant cooling system usually promotes the thermally uniform environment and the reduced draft risk (Murakami et al. 2015). However, higher indoor air temperature drifts may provide higher dissatisfaction with radiant systems (Kolarik et al. 2015).

Chilled ceiling is a radiant system which can be combined with an air distribution system to provide fresh air for the occupants (Mustakallio et al. 2017b). In those systems, the additional cooling or heating is usually generated by a water circulation in the system. The chilled ceiling may offer a promising system that improves the ventilation performance and energy efficiency (Schiavon et al. 2012; Schiavon et al. 2015; Wu et al. 2019). Furthermore, a draft risk can also be reduced by conducting a chilled ceiling system, because a small air movement with the radiant cooling system can improve the comfortable sensation (Kitagawa et al. 1999; Corgnati et al. 2009). The main characteristics of chilled ceiling are the cooling capacity, the portion of convection and radiation as well as the dynamic response on changing thermal environment (Novoselac and Srebric 2002). However, the distribution of heat sources and the surface temperatures may affect considerably the panel performance (Fonseca Diaz and Cuevas 2011). Moreover, the chilled ceiling may dampen thermal plumes at a cold surface (Chen et al. 2013).

Active chilled beam system, in turn, is a conventional system comprised of the supplied airflow and a water circulation in the cooling coil. The chilled beam systems are energy-efficient solutions for the indoor environments that require individual zone control and involve moderate humidity sources (Woollett and Rimmer 2015; Nam and Zhai 2019). The chilled beam operates by induction so that the supplied fresh air is mixed with the entering room air in the system (Mustakallio et al. 2017a). Therefore, the chilled-beam may generate larger airflow movement than the chilled-ceiling system. The airflow pattern is not stable and the area of draught risk may variate in time and due to changes in room heat sources (Koskela et al. 2010). In addition, the increased draft risk have been found in the areas where the supply air jets turn down to the 
occupied zone (Koskela et al. 2012). The active chilled beams may provide better thermal comfort with the symmetrical heat sources than with the asymmetrical ones (Wu et al. 2018a).

In earlier studies, no significant differences have been found between the chilled-beam, radiant-panel and chilled ceiling systems on thermal environment (Kosonen et al. 2011; Duszyk et al. 2011; Bolashikov et al. 2014). Minor differences were found between a convective system and combined convective and radiant systems in office environments (Mustakallio et al. 2016; Mustakallio et al. 2017a). However, earlier studies have found significant effects of heat gain strength and distribution on indoor airflows (Kosonen et al. 2010; Koskela et al. 2010; Lipczynska et al. 2015; Nielsen et al., 2017). Furthermore, a recent study concludes that the radiant systems may provide equal or better thermal comfort compared to all-air convective systems (Karmann et al. 2017), which is in agreement with an another study where the radiant ceiling achieved the most uniform comfort conditions (Le Dréau and Heiselberg 2014). In addition, a radiant cooling system can provide the equivalent thermal comfort at a higher air temperature and decrease the draft risk by operating with smaller airflow than the conventional systems (Rhee et al. 2017). Altogether, Mustakallio et al. (2016) stated that the convective and radiant cooling systems provided only slight differences in office thermal environments and a major factor on indoor airflows was a heat gain distribution. However, less attention has been paid to a local draft risk in the occupied zone and the descriptive statistics of the air temperature, air speed and draft risk.

In this study, the diffuse ceiling ventilation (DCV), the chilled beam system (CB) and the chilled ceiling combined with mixing ventilation (CCMV) were compared. The motivation was to provide new knowledge on the convective and radiant cooling systems, the airflow characteristics and the local draft discomfort in office environment. The draft is defined as an unwanted local cooling of the body caused by air movement (ASHRAE 2017). The novelty of this study lies in comparing those advanced and topical ventilation and air conditioning methods while reducing draft discomfort and maintaining thermal conditions. New knowledge are necessary in the future while developing the intelligent office environments, in which the user centric environment and the advanced systems interact on the changes in thermal environment. The objective was to investigate the effects of heat gain strength on the air temperature, air speed and draft risk in the occupied zone. The study will contribute to the building sciences, indoor airflows, heat gains and air distribution in 
thermal environments. In the future, the radiant and ventilative cooling methods could play a central role when responding temporal and spatial changes in indoor climate.

\section{Methods}

\section{Test chambers}

Experiments were carried out in two test chambers under stable thermal conditions. The results of these measurements have been reported earlier by Mustakallio et al. (2016), Mustakallio et al. (2017a) and Lestinen et al. (2018b). This study adds knowledge on differences of thermal conditions and draft discomfort with the studied systems. The CCMV and CB systems were studied in the test chamber 1 with the internal dimensions of $4.1 \mathrm{~m}$ (length), $4.2 \mathrm{~m}$ (width) and $2.9 \mathrm{~m}$ (height) (Figure 1a). The DCV system was studied in the test chamber 2 with the internal dimensions of $5.5 \mathrm{~m}$ length, $3.8 \mathrm{~m}$ width and $3.2 \mathrm{~m}$ height (Figure 1b). A double office layout was located at the perimeter area $0.6 \mathrm{~m}$ away from the heated window panels in both test chambers.

The experimental setups were designed according to recommendations by the EN 15251 standard (CEN 2007) in which the target level for indoor environment was category II. Heat gains from sedentary occupants, computers, lighting and solar thermal radiation were modelled. Zukowska et al. (2012) showed that a thermal manikin and a seated dummy may simulate human thermal plumes properly. The target indoor air temperature was $26 \pm 0.5^{\circ} \mathrm{C}$ and the measurement locations were divided equally (Figure 1). 

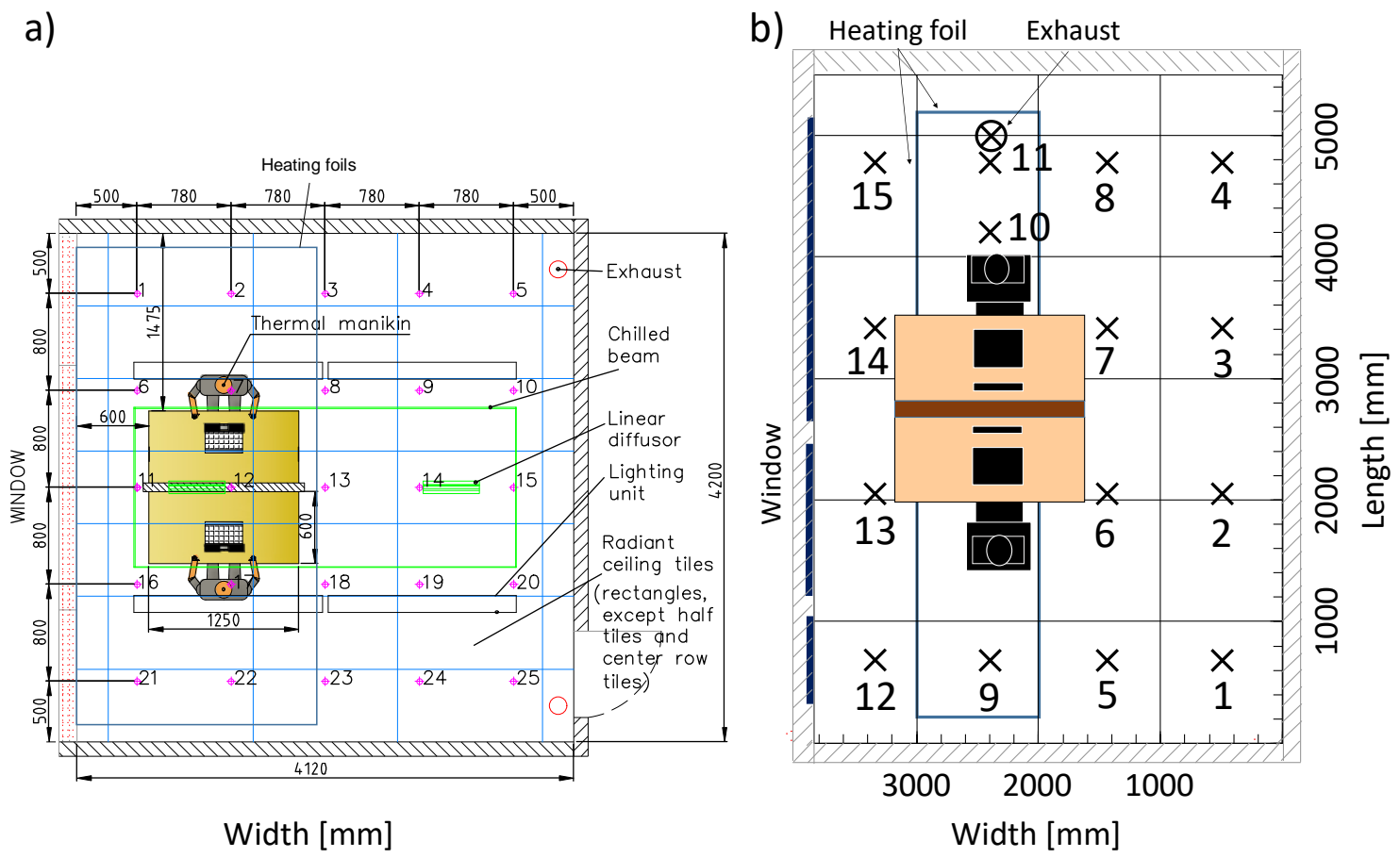

Figure 1. Top-view of test chambers and the measurement locations: a) Test chamber 1 with CB and CCMV systems. The measured locations are marked as 1-25. b) Test chamber 2 with DCV system. The measured locations are marked as 1-15.

\section{Control systems of indoor climate}

The CCMV and the CB systems are air-water systems where the majority of the cooling power is covered with water side. The DCV system, in turn, has a ventilative cooling mechanism that controls a thermal environment by adjusting ventilation rate and supply air temperature.

In the CCMV system, the cooling panels were installed into the suspended ceiling at the height of $2.9 \mathrm{~m}$ (Figure 2a). The cooling panels covered $77 \%\left(13 \mathrm{~m}^{2}\right)$ of the total ceiling area. The top of suspended ceiling was not insulated. Two linear diffusers of $472 \mathrm{~mm}$ x $20 \mathrm{~mm}(\mathrm{LxH})$ were installed to distribute supplied air in two directions to the test chamber.

In the $\mathrm{CB}$ system, an exposed chilled beam of a total length of $3.0 \mathrm{~m}$ and a coil length of $2.1 \mathrm{~m}$ was installed at the height of $2.5 \mathrm{~m}$ (Figure 2b). In the CB system, the supplied outdoor air is mixed with induced 
indoor air that is flowing through the cooling coil before the mixed supply air is delivered into the room. The solution has a small space requirements for ducting and a good flexibility in office environments. (True et al. 2007). Also in this method, the supplied mixed airflows were directed in two directions.

In the DCV system, a uniformly perforated suspended ceiling was installed to bring supply air down to the occupied zone (Figure $2 \mathrm{c}$ ). The perforation rate was $0.50 \pm 0.02 \%$ of the ceiling area and the nozzles had a diameter of $14 \mathrm{~mm}$ each. The nozzle rows closest to the walls were sealed.

In the test chamber 1, the indoor air was extracted from near the corridor wall at the height of $2.9 \mathrm{~m}$ by installing one exhaust valve at both corner (Figure 1a). In the test chamber 2, the indoor air was extracted from the suspended ceiling at the height of $3.2 \mathrm{~m}$ near the location 11 (Figure 1b). 

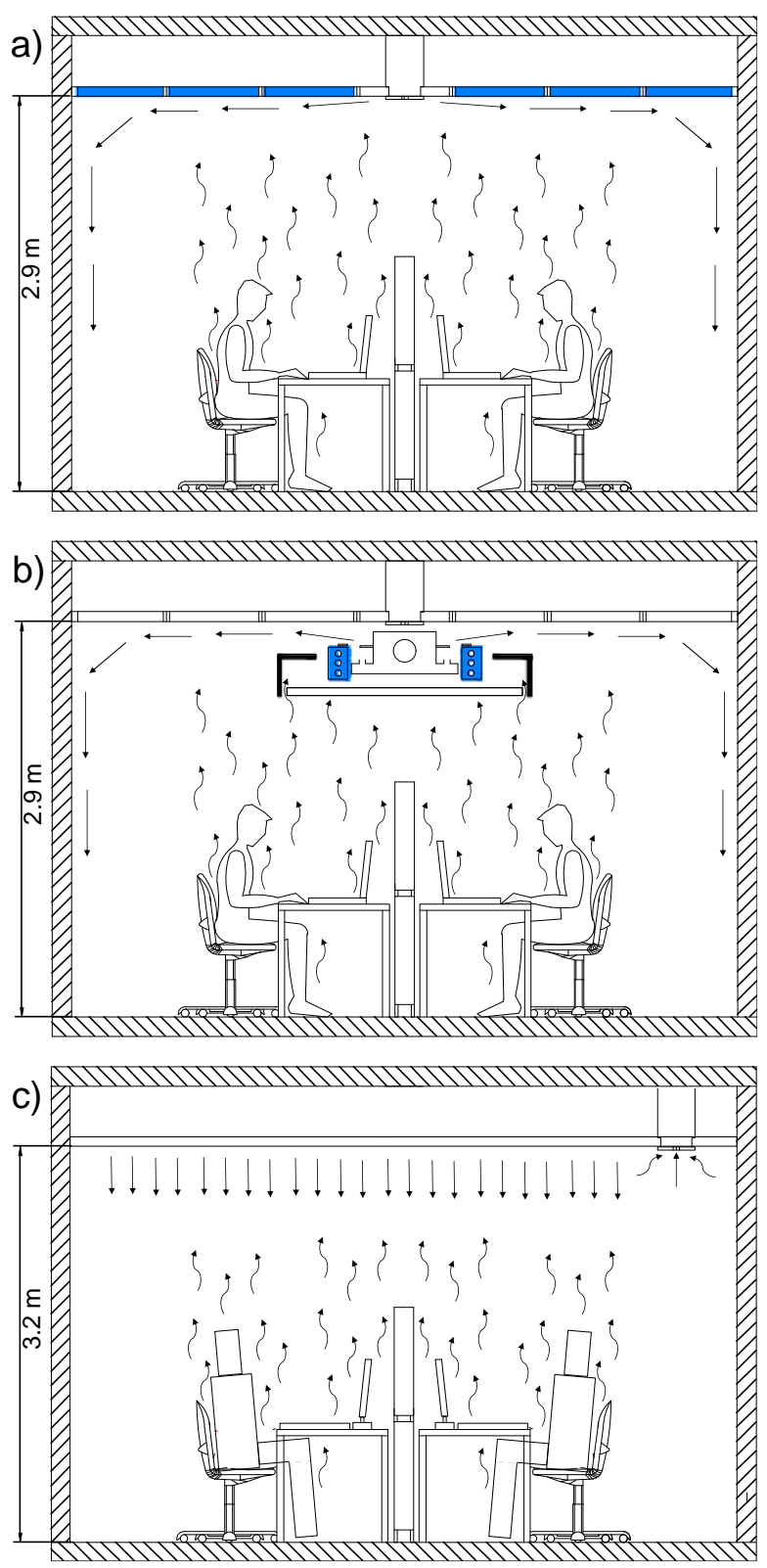

Figure 2. Schematic principle of indoor airflows: a) The chilled ceiling with mixing ventilation system (CCMV). b) The chilled beam system (CB). c) The diffuse ceiling ventilation system (DCV).

\section{Indoor airflow measurement}

Low-velocity thermal anemometers with omnidirectional velocity sensor were installed at the heights of $0.1 \mathrm{~m}, 0.6 \mathrm{~m}, 1.1 \mathrm{~m}$, and $1.7 \mathrm{~m}$ according to recommendation of the standard EN ISO 7726 (CEN 2001). 
Measurement period in each measurement point was 5 min for the CB and CCMV systems, and $1 \mathrm{~h}$ for the DCV system. Accuracy of the measurement instruments are shown in Table 1.

Table 1. Measuring instruments.

\begin{tabular}{|c|c|c|}
\hline Meter-type & Variable & Accuracy \\
\hline $\begin{array}{l}\text { Low velocity thermal anemometer } \\
\text { with omnidirectional velocity sensor } 1 \\
\text { (test chamber } 1 \text { ) }\end{array}$ & $\begin{array}{c}\text { Air temperature } \\
\text { Air speed } \\
\text { (at height } 0.1 \mathrm{~m}-1.7 \mathrm{~m} \text { ) }\end{array}$ & $\begin{array}{c}\text { Air speed: } \\
\pm 0.02 \mathrm{~m} / \mathrm{s} \pm 1 \% \text { of reading } \\
\text { Air temperature: } \\
\pm 0.2^{\circ} \mathrm{C} \\
\text { STDerr }<10 \% \text { up to } 1.5 \mathrm{~Hz}\end{array}$ \\
\hline $\begin{array}{l}\text { Low velocity thermal anemometer } \\
\text { with omnidirectional velocity sensor } 2 \\
\text { (test chamber } 2 \text { ) }\end{array}$ & $\begin{array}{c}\text { Air temperature } \\
\text { Air speed } \\
\text { (at height } 0.1 \mathrm{~m}-1.1 \mathrm{~m} \text { ) }\end{array}$ & $\begin{array}{c}\text { Air speed: } \\
\pm 0.01 \mathrm{~m} / \mathrm{s} \pm 2.5 \% \text { of reading } \\
\text { Air temperature: } \\
\pm 0.15^{\circ} \mathrm{C} \\
\text { STDerr }<10 \% \text { up to } 2 \mathrm{~Hz}\end{array}$ \\
\hline $\begin{array}{l}\text { Low velocity thermal anemometer } \\
\text { with omnidirectional velocity sensor } 3 \\
\text { (test chamber } 2 \text { ) }\end{array}$ & $\begin{array}{c}\text { Air temperature } \\
\text { Air speed } \\
\text { (at height } 1.4 \mathrm{~m}-2.9 \mathrm{~m})\end{array}$ & $\begin{array}{c}\text { Air speed: } \\
\pm 0.02 \mathrm{~m} / \mathrm{s} \pm 1.5 \% \text { of reading } \\
\text { Air temperature: } \\
\pm 0.2^{\circ} \mathrm{C} \\
\text { STDerr }<10 \% \text { up to } 1.5 \mathrm{~Hz}\end{array}$ \\
\hline Tinytag data logger & Air temperature & $\pm 0.5^{\circ} \mathrm{C}\left(0 \ldots+45^{\circ} \mathrm{C}\right)$ \\
\hline Infrared camera & Surface temperature & $\pm 2^{\circ} \mathrm{C}$ or $\pm 2 \%$ of reading \\
\hline Infrared thermometer & Surface temperature & $\pm 1^{\circ} \mathrm{C}$ or $\pm 1 \%$ of reading \\
\hline Measuring instrument & Pressure difference & $\begin{array}{c} \pm 0.3 \% \text { of reading } \\
\text { lowest } \pm 0.3 \mathrm{~Pa}\end{array}$ \\
\hline Regulation and measuring device & Airflow rate & $\pm 5 \%$ \\
\hline
\end{tabular}

The measured physical quantities were the air temperature and the air speed in the occupied zone and the pressure difference at the measuring devices of supplied air and exhaust air for estimating the airflow rate. The draft risk model defined by EN ISO 7730 standard (CEN, 2005) was used. The draft risk is expressed as

$$
D R=\left(34-t_{a, l}\right)\left(\bar{u}_{a, l}-0.05\right)^{0.62}\left(0.37 \cdot \bar{u}_{a, l} \cdot T u+3.14\right),
$$

where $t_{a, l}\left[{ }^{\circ} \mathrm{C}\right]$ is the local air temperature, $\bar{u}_{a, l}[\mathrm{~m} / \mathrm{s}]$ is the local mean air velocity, and $T u[\%]$ is the local turbulence intensity. The model is suitable for the people at light activity, e.g. for a sedentary person. However, the model may overestimate the predicted draft risk at the level of arms and feet. The measurement uncertainty is around 5\% percentage points (p.p.) for the draft risk (Melikov et al. 2007b). 


\section{Test cases}

The test case parameters are shown in Table 2. With the CB and CCMV systems, the supply air temperature was kept at $16 \pm 0.5^{\circ} \mathrm{C}$. In the water cooling systems, the inlet water temperature was kept at $15 \pm 0.5^{\circ} \mathrm{C}$ and the return water temperature was $2-3^{\circ} \mathrm{C}$ warmer than the inlet water temperature. With the $\mathrm{DCV}$ system, the supply air temperature was kept at $17 \pm 0.5^{\circ} \mathrm{C}$. One degree difference from $16^{\circ} \mathrm{C}$ was considered acceptable, because $1{ }^{\circ} \mathrm{C}$ increase in supply air temperature has earlier been shown to have a small effect on the averaged airflow characteristics (Lestinen et al. 2018a).

In the test chamber 1, the surface temperature of heated water panels simulated a solar heat gain from the windows. The direct solar heat gain was simulated by using 5 electrical heated foils of $2.0 \mathrm{~m} \mathrm{x} 0.75 \mathrm{~m}$ $(\mathrm{L} x \mathrm{~W})$ which were connected in parallel and placed on the floor next to the window wall (Figure 1). The heated window area was $6.3 \mathrm{~m}^{2}$. In the test chamber 2, a heating foil of $5 \times 1 \mathrm{~m}^{2}(\mathrm{~L} \mathrm{x} \mathrm{W})$ was used and the window area was $7.5 \mathrm{~m}^{2}$.

Table 2. Test case factors for the usual heat gains and the peak heat gains.

\begin{tabular}{|c|c|c|c|c|c|}
\hline Test chamber 1: CB, CCMV & $\begin{array}{l}\text { Usual } \\
\text { gains }\end{array}$ & $\begin{array}{l}\text { Peak } \\
\text { gains }\end{array}$ & Test chamber 2: DCV & $\begin{array}{l}\text { Usual } \\
\text { gains }\end{array}$ & $\begin{array}{l}\text { Peak } \\
\text { gains }\end{array}$ \\
\hline Floor area, $\mathrm{m}^{2}$ & 17.3 & 17.3 & Floor area, $\mathrm{m}^{2}$ & 21.0 & 21.0 \\
\hline Heat gain, W/floor-m² & 37 & 64 & Heat gain, W/floor- $\mathrm{m}^{2}$ & 40 & 57 \\
\hline $2 \mathrm{x}$ Thermal manikin, $\mathrm{W}$ & 156 & 156 & $2 \mathrm{x}$ Test dummy, W & 176 & 176 \\
\hline $2 \times$ computer, $\mathrm{W}$ & 130 & 130 & $2 \mathrm{x}$ computer, $\mathrm{W}$ & 96 & 96 \\
\hline $2 \times$ monitor, $\mathrm{W}$ & 0 & 0 & $2 \mathrm{x}$ monitor, $\mathrm{W}$ & 70 & 70 \\
\hline Lighting, W & 160 & 160 & Lighting, W & 116 & 116 \\
\hline Solar-load at window, $\mathrm{W} \sim$ & 202 & 404 & Solar-load at window*, $\mathrm{W} \sim$ & 381 & 317 \\
\hline Solar-load at floor, W & 0 & 250 & Solar-load at floor*, W & 0 & 420 \\
\hline Total heat gain, $\mathrm{W}$ & 648 & 1100 & Total heat gain, $\mathrm{W}$ & 839 & 1195 \\
\hline Supply airflow rate, $1 / \mathrm{s}, \mathrm{m}^{2}$ & 1.5 & 1.5 & Supply airflow rate, $1 / \mathrm{s}, \mathrm{m}^{2}$ & 3.6 & 5.2 \\
\hline Supply air temperature, ${ }^{\circ} \mathrm{C}$ & 16 & 16 & Supply air temperature, ${ }^{\circ} \mathrm{C}$ & 17 & 17 \\
\hline Room air temperature, ${ }^{\circ} \mathrm{C}$ & 26 & 26 & Exhaust air temperature,${ }^{\circ} \mathrm{C}$ & 26 & 26 \\
\hline Supply air cooling, W/floor-m ${ }^{2}$ & -18 & -18 & Supply air cooling, W/floor- $\mathrm{m}^{2}$ & -40 & -57 \\
\hline Water cooling, W/floor-m ${ }^{2}$ & -19 & -46 & Water cooling, W/floor-m ${ }^{2}$ & 0 & 0 \\
\hline
\end{tabular}

* The solar load at window was adjusted lower at the peak gains, because the heating foil generated a constant power. 


\section{Results}

\section{Air temperature}

The room air temperature results are summarized in Table 3 . The average air temperature was set to be $26^{\circ} \mathrm{C}$ in all systems. However, there were slight variations with the average room temperature. At the usual heat gain conditions, the range of local mean air temperatures was largest with the DCV and smallest with the CCMV system. However, the uncertainty of measurements was on the order of $\pm 0.2^{\circ} \mathrm{C}$. The standard deviation was at the same level for all the studied systems. At the peak heat gain conditions, the CCMV system had the largest range and the CB system had the smallest range. The standard deviation increased with the heat gain strength. The largest standard deviation was observed with the CCMV and smallest with the DCV at the peak heat gain level. The horizontal air temperature difference between the perimeter area and the corridor area was largest with the CCMV and smallest with the DCV at both the heat gain strengths. At the usual heat gain strength, the horizontal air temperature differences were between $0.5-0.7^{\circ} \mathrm{C}$ with the studied systems. At the peak heat gain strength, the corresponding differences were $0.8-1.1^{\circ} \mathrm{C}$. The vertical air temperature differences were quite a similar level with those systems. The vertical differences were slightly larger with the CCMV and the CB systems than with the DCV system. However, the average differences were within the uncertainty in measurement. Consequently, there were only minor differences in the air temperature profiles between the studied systems.

Table 3. Descriptive statistics of local mean air temperatures in the occupied zone, where $n$ denotes the number of locations. Uncertainty in measurement is $\pm 0.2^{\circ} \mathrm{C}$.

\begin{tabular}{|c|c|c|c|c|c|c|}
\hline Double office layout & \multicolumn{3}{|c|}{ Usual heat gain } & \multicolumn{3}{|c|}{ Peak heat gain } \\
\hline At heights $0.1 \mathrm{~m}, 0.6 \mathrm{~m}, 1.1 \mathrm{~m}$ and $1.7 \mathrm{~m}$ & $\begin{array}{c}\text { CCMV } \\
37 \\
\text { W/m } \\
(n=87)\end{array}$ & $\begin{array}{c}\mathrm{CB} \\
37 \\
\mathrm{~W} / \mathrm{m}^{2} \\
(n=88)\end{array}$ & $\begin{array}{c}\mathrm{DCV} \\
40 \\
\mathrm{~W} / \mathrm{m}^{2} \\
(n=60)\end{array}$ & $\begin{array}{c}\mathrm{CCMV} \\
64 \\
\mathrm{~W} / \mathrm{m}^{2} \\
(n=88)\end{array}$ & $\begin{array}{c}\mathrm{CB} \\
64 \\
\mathrm{~W} / \mathrm{m}^{2} \\
(n=87)\end{array}$ & $\begin{array}{c}\mathrm{DCV} \\
57 \\
\mathrm{~W} / \mathrm{m}^{2} \\
(n=60)\end{array}$ \\
\hline Average air temperature $\left[{ }^{\circ} \mathrm{C}\right]$ & 26.0 & 25.8 & 25.6 & 26.1 & 25.8 & 25.9 \\
\hline Standard deviation of air temperature $\left[{ }^{\circ} \mathrm{C}\right]$ & 0.3 & 0.3 & 0.3 & 0.6 & 0.5 & 0.4 \\
\hline Range of local mean air temperatures $\left[{ }^{\circ} \mathrm{C}\right]$ & 1.3 & 1.4 & 1.7 & 2.7 & 1.8 & 2.1 \\
\hline $\begin{array}{c}\text { Average of horizontal differences from window side to } \\
\text { corridor side at height } 1.1 \mathrm{~m}\left[{ }^{\circ} \mathrm{C}\right]\end{array}$ & 0.7 & 0.6 & 0.5 & 1.1 & 1.0 & 0.8 \\
\hline $\begin{array}{l}\text { Average of absolute differences between height } 0.1 \mathrm{~m} \\
\text { and } 1.7 \mathrm{~m}\left[{ }^{\circ} \mathrm{C}\right]\end{array}$ & 0.3 & 0.4 & 0.2 & 0.4 & 0.4 & 0.3 \\
\hline
\end{tabular}




\section{Air speed}

The mean air speed results are summarized in Table 4 . The spatially averaged mean air speeds were quite a similar with all the studied systems. At the usual heat gain conditions, the local maximum of mean air speeds was $0.23 \mathrm{~m} / \mathrm{s}$ with the CCMV, $0.27 \mathrm{~m} / \mathrm{s}$ with the CB and $0.25 \mathrm{~m} / \mathrm{s}$ with the DCV system. At the peak heat gain strength, the corresponding maximum air speeds were $0.24 \mathrm{~m} / \mathrm{s}, 0.29 \mathrm{~m} / \mathrm{s}$ and $0.30 \mathrm{~m} / \mathrm{s}$, respectively. Hence, the maximum mean air speed was slightly lower with the CCMV system than with those other studied systems. This is rather reasonable, because the indoor water cooling system usually reduces the required ventilation rate if a sufficient amount of clean air has been supplied to occupants. Moreover, although the chilled beam system includes a water cooling system, the total supply air movement increases due to induced secondary airflow, compared to the CCMV system. Obviously therefore, the maximum mean air speed was highest with the CB system at the usual heat gain level. However, at the peak heat gain conditions, the DCV system provided the highest maximum air speed level, but only slightly higher than with the CB system. This is also reasonable, because the DCV system operates without a water cooling system except a cooling coil of air handling unit. This means that the necessary cooling is controlled by the ventilation rate if the supply air temperature is kept constant.

Consequently, a smaller share of high air speed $(>0.2 \mathrm{~m} / \mathrm{s})$ locations was obtained with the CCMV than with the other studied systems. At the usual heat gain conditions, a considerably larger share was observed with the CB system than with the other ones. However, at the peak heat gain conditions, the largest share was obtained with the DCV system. This shows clearly the effect of increased ventilation rate on air speed levels. In contrast, the DCV system provided also the largest share of low air speed $(<0.1 \mathrm{~m} / \mathrm{s})$ locations at the usual heat gain conditions, together with the CCMV system. Furthermore, both the CB system and the DCV system produced the largest share of low velocity locations at the peak heat gain conditions. This means that the CCMV system provided the largest share of locations under the both heat gain strengths while the mean air speed level was from $0.1 \mathrm{~m} / \mathrm{s}$ to $0.2 \mathrm{~m} / \mathrm{s}$. At this stage, the smallest share was obtained generally with the DCV system.

The spatial standard deviation ranged from 31 to $42 \%$ over the average air speed level, with the CCMV being the lowest and the DVC the highest particularly at the peak heat gain conditions. This indicates that the CCMV system created a slightly more stable airflow field than those other studied systems. Furthermore, 
the average air speed was lower on the window side than on the corridor side of the room. This indicates a circulating airflow pattern from heat sources to other side of room which was also observed with a marker smoke visualisation (Mustakallio et al., 2016; Lestinen et al., 2018b).

Table 4. The mean air speed in the occupied zone, where $u$ denotes the air speed. Uncertainty in measurement is $\pm d u= \pm(0.025+0.025 \bar{u})$ (Melikov et al. 2007b).

\begin{tabular}{|c|c|c|c|c|c|c|}
\hline Double office layout & \multicolumn{3}{|c|}{ Usual heat gain } & \multicolumn{3}{|c|}{ Peak heat gain } \\
\hline At heights $0.1 \mathrm{~m}, 0.6 \mathrm{~m}, 1.1 \mathrm{~m}$ and $1.7 \mathrm{~m}$ & $\begin{array}{c}\text { CCMV } \\
37 \\
\mathrm{~W} / \mathrm{m}^{2} \\
(n=87)\end{array}$ & $\begin{array}{c}\mathrm{CB} \\
37 \\
\mathrm{~W} / \mathrm{m}^{2} \\
(n=82)\end{array}$ & $\begin{array}{c}\mathrm{DCV} \\
40 \\
\mathrm{~W} / \mathrm{m}^{2} \\
(n=60)\end{array}$ & $\begin{array}{c}\mathrm{CCMV} \\
64 \\
\mathrm{~W} / \mathrm{m}^{2} \\
(n=87)\end{array}$ & $\begin{array}{c}\mathrm{CB} \\
64 \\
\mathrm{~W} / \mathrm{m}^{2} \\
(n=86)\end{array}$ & $\begin{array}{c}\mathrm{DCV} \\
57 \\
\mathrm{~W} / \mathrm{m}^{2} \\
(n=60)\end{array}$ \\
\hline Average air speed $[\mathrm{m} / \mathrm{s}]$ & 0.11 & 0.12 & 0.11 & 0.13 & 0.13 & 0.14 \\
\hline Standard deviation of mean air speeds $[\mathrm{m} / \mathrm{s}]$ & 0.04 & 0.05 & 0.05 & 0.04 & 0.05 & 0.06 \\
\hline Max. mean air speed $[\mathrm{m} / \mathrm{s}]$ & 0.23 & 0.27 & 0.25 & 0.24 & 0.29 & 0.30 \\
\hline Std. dev. / avg [-] & 0.36 & 0.42 & 0.41 & 0.31 & 0.38 & 0.42 \\
\hline Avg. air speed in window side $[\mathrm{m} / \mathrm{s}]$ & 0.10 & 0.09 & 0.11 & 0.13 & 0.12 & 0.13 \\
\hline Avg. air speed in corridor side $[\mathrm{m} / \mathrm{s}]$ & 0.14 & 0.14 & 0.12 & 0.17 & 0.14 & 0.16 \\
\hline Difference from window to corridor side $[\mathrm{m} / \mathrm{s}]$ & 0.04 & 0.05 & 0.01 & 0.04 & 0.02 & 0.03 \\
\hline Share of locations $u<0.1 \mathrm{~m} / \mathrm{s}[-]$ & 0.48 & 0.41 & 0.50 & 0.25 & 0.30 & 0.30 \\
\hline Share of locations $0.1 \leq u \leq 0.2 \mathrm{~m} / \mathrm{s}[-]$ & 0.48 & 0.48 & 0.45 & 0.67 & 0.60 & 0.57 \\
\hline Share of locations $u>0.2 \mathrm{~m} / \mathrm{s}[-]$ & 0.03 & 0.11 & 0.05 & 0.08 & 0.09 & 0.13 \\
\hline
\end{tabular}

\section{Draft risk}

The draft risk results are summarized in Table 5. The average draft risk was below $10 \%$ in the studied cases except with the CB system at the peak heat gain strength. Furthermore, the standard deviation was smallest with the CCMV, indicating more uniform conditions. Generally, the range of maximum draft risks was 13$18 \%$ at the usual heat gain and $16-21 \%$ at the peak heat gain conditions. The largest maximum of local draft risks was obtained with the CB system and the smallest one with the CCMV system. However, the maximum draft risk was at the same level with both the CB and the DCV systems. Consequently, the results indicate that a classification for thermal environment is the category B defined by EN ISO 7730 standard (CEN, 2005) for the studied systems apart from the CB system at the peak heat gain conditions which falls into the category C.

Although the average draft risk was at a same level with the studied systems, a share of locations, in which the draft risk was lower than $10 \%$, was the largest with the CCMV system and the smallest with the CB system. However, those shares were more near each other while the heat gain was increased at the peak heat gain level. Generally, the draft risk was smaller in the window side than in the corridor side. This may 
be explained by the observed airflow patterns from the heat sources to the other side of the room. The results also imply that the radiant cooling may reduce the draft discomfort more efficiently than the convective cooling.

Table 5. The draft risk in the occupied zone. Uncertainty in measurement $\pm 5 \%$ (p.p.) (Melikov et al. 2007b).

\begin{tabular}{|c|c|c|c|c|c|c|}
\hline Double office layout & \multicolumn{3}{|c|}{ Usual heat gain } & \multicolumn{3}{|c|}{ Peak heat gain } \\
\hline At heights $0.1 \mathrm{~m}, 0.6 \mathrm{~m}, 1.1 \mathrm{~m}$ and $1.7 \mathrm{~m}$ & $\begin{array}{c}\text { CCMV } \\
37 \\
\mathrm{~W} / \mathrm{m}^{2} \\
(n=87)\end{array}$ & $\begin{array}{c}\mathrm{CB} \\
37 \\
\mathrm{~W} / \mathrm{m}^{2} \\
(n=82)\end{array}$ & $\begin{array}{c}\text { DVC } \\
40 \\
\mathrm{~W} / \mathrm{m}^{2} \\
(n=60)\end{array}$ & $\begin{array}{c}\text { CCMV } \\
64 \\
\mathrm{~W} / \mathrm{m}^{2} \\
(n=87)\end{array}$ & $\begin{array}{c}\mathrm{CB} \\
64 \\
\mathrm{~W} / \mathrm{m}^{2} \\
(n=86)\end{array}$ & $\begin{array}{c}\text { DVC } \\
57 \\
\mathrm{~W} / \mathrm{m}^{2} \\
(n=60)\end{array}$ \\
\hline Average draft risk [\%] & 6 & 8 & 7 & 8 & 10 & 9 \\
\hline Standard deviation of draft risk [\%] & 3 & 5 & 4 & 3 & 5 & 5 \\
\hline Max. draft risk [\%] & 13 & 18 & 18 & 16 & 21 & 19 \\
\hline Std. dev. / avg [-] & 0.49 & 0.59 & 0.57 & 0.42 & 0.48 & 0.52 \\
\hline Avg. draft risk in window side [\%] & 5 & 4 & 6 & 7 & 7 & 8 \\
\hline Avg. draft risk in corridor side [\%] & 8 & 9 & 8 & 11 & 10 & 11 \\
\hline Difference from window to corridor side [\%] & 4 & 5 & 2 & 4 & 3 & 3 \\
\hline Share of locations $D R<10 \%[-]$ & 0.94 & 0.67 & 0.85 & 0.68 & 0.58 & 0.65 \\
\hline Share of locations $10 \% \leq D R \leq 20 \%[-]$ & 0.06 & 0.33 & 0.15 & 0.32 & 0.41 & 0.35 \\
\hline Share of locations $D R>20 \%[-]$ & 0.00 & 0.00 & 0.00 & 0.00 & 0.01 & 0.00 \\
\hline
\end{tabular}

Figure 3 shows a color map of the maximum draft risks in the occupied zone at the peak heat gain conditions from the height of $0.1 \mathrm{~m}$ up to $1.7 \mathrm{~m}$ at each measured location (Figure 1). The results show that the draft risk level was larger in the corridor side than in the window side, in which the heat sources existed. In addition, the results indicate that the CCMV system provided the lowest maximum draft risk levels, actually only slightly above $10 \%$ at the workstations. Furthermore, the CCMV system provided slightly larger maximum draft risks in the door corner compared to other regions of the room (Figure 3a). The CB system, in turn, produced the larger maximum rates in the upper-corner on the right (Figure 3b). In the DCV system, the maximum draft risk occurred at the both end-sides and in the middle of the room (Figure 3c). However, only the CB system provided over $20 \%$ maximum draft risk at the upper end-side of room (Figure $3 \mathrm{~b}$ ). This may imply that the limited zones in the room can have the category A conditions for thermal environment (EN ISO 7730) e.g. at the workstation area, but it is very difficult to achieve those conditions for the whole occupied zone. 
a)

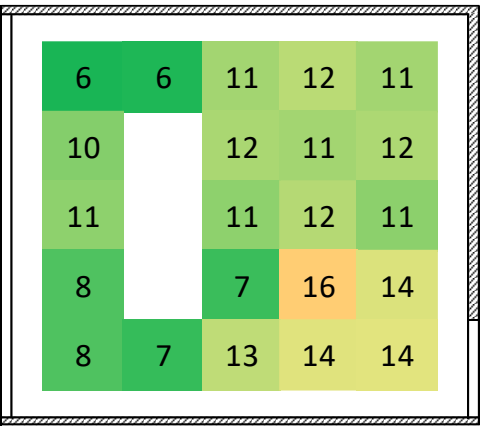

b)

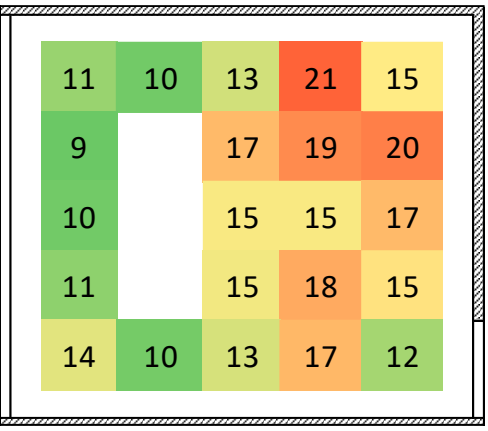

c)

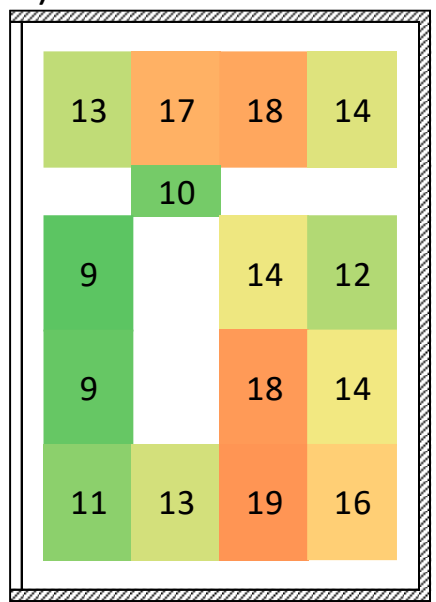

Figure 3. The maximum draft risk (EN ISO 7730) of the heights from $0.1 \mathrm{~m}$ to $1.7 \mathrm{~m}$ at each location. a) The CCMV system (Mustakallio et al. 2013), b) the CB system (Mustakallio et al. 2013) and c) the DCV system at the peak heat gain conditions.

\section{Discussion}

The study adds new knowledge on comparing topical cooling systems that were based on earlier studies by Mustakallio et al. (2016), Mustakallio et al. (2017a) and Lestinen et al. (2018b). New knowledge may inspire new studies on comparing the advanced cooling systems and continue scientific discussion on draft discomfort in the office environments. The measurements were carried out in two separate test chambers. Therefore, the most obvious limitation is the slight differences between those chambers. However, the relative locations of heat sources and cooling systems are rather similar that, in turn, has been shown to have a main effect on room airflow patterns (Kosonen et al. 2010; Nielsen 2011; Koskela et al. 2012). Furthermore, the height levels were similar in the experimental setups. The usual heat gain strength was $8 \%$ higher and the peak heat gain level was $11 \%$ lower with the DCV system than with those CCMV and CB systems. This means that the draft risk levels may slightly decrease at the usual heat gain conditions and increase slightly at the peak heat gain conditions by using the DCV system, if exactly similar heat gains are obtained (Lestinen et al. 2019). Therefore, the given results may even highlight slightly the use of radiant systems at the high heat gain levels while reducing the draft discomfort. 
The results show that the studied systems provided rather similar performance between the perimeter area and the corridor side of the room. Furthermore, the vertical air temperature differences were quite similar. The buoyancy flows and air distribution flows had considerable effects on thermal environment. The convection flows drive the indoor airflows with increasing strength of heat sources. The commonly used workstation layout provided asymmetric heat gain distribution in the both test chambers. The heat sources produced a circulating airflow pattern from the perimeter area to the opposite corridor side. The buoyancy flows pushed also the supplied ventilation jets to the opposite side. This could be prevented by increasing the momentum of ventilation jets. However, this may increase the draft risk correspondingly. However, at $26^{\circ} \mathrm{C}$ air temperature levels, people may require air movement to improve satisfaction with thermal environment. In addition, thermal radiation affects a human sensation. Thus, the sensation is warmer near a heat source than further away from the source. In any case, there were no significant differences with the studied systems compared to uncertainty levels. The result is in agreement with findings of earlier studies (Mustakallio et al. 2016; Kosonen et al. 2011; Duszyk et al. 2011).

The further studies are recommended on advanced air distribution and cooling systems to improve knowledge and understanding of future user-centric indoor environments. This could highlight the open-plan offices where the interaction of convection flows can be complex due to numerous workstations, the indoor air may flow to the different facades and the thermal radiation can increase on ceiling due to larger view factor. In addition, the volume of indoor environment impact on the indoor airflows generated by ventilation jets and heat sources. The airflow elements may interact differently in large and small environments, because their relative locations may differ and the room height can be different (Lin et al. 2006; Lin et al. 2009; Koskela et al. 2010; Nielsen et al. 2015).

The buoyancy and air distribution flows can be reduced by decreasing the heat sources and by using the low-velocity systems. The possible system is also a perimeter chilled beam installation with a ceiling opening and a plenum cavity that will capture thermal plumes over the window (Woollett and Rimmer 2015). The ventilation rate can be decreased to a smaller level by using the radiant panels under the high heat gain conditions. Furthermore, an integration of radiant panel in chilled-beam design can increase the uniformity of thermal environment (Mustakallio et al. 2017a). In addition, the indoor air temperature can be kept at a higher level than without the radiant panels (Le Dréau and Heiselberg 2014). A recent study shows that the 
cooling capacity of radiant ceiling can be enhanced by conducting a distributed panel layout instead of a centralized layout (Shin et al. 2019). Moreover, a radiant ceiling cooling may compensate the presence of warm surfaces in the chamber, resulting similar indoor air and operative temperatures (Kazanci et al. 2018; Jia et al. 2018). In addition, the air velocity around the panel surface impact on the cooling performance (Tian et al. 2012).

The results indicate that all those studied methods are appropriate for the given heat gain levels. The draft risk levels were mainly below $20 \%$, which means that the draft risk was acceptable for the thermal environment defined by ASHRAE Standard 55 (ASHRAE 2017). However, none of the studied systems achieved the category A defined by EN ISO 7730 (CEN 2005) even at the usual heat gain conditions. However, since the uncertainty of draft risk can be on the order of 5\% p.p. (Melikov et al. 2007b), there is a corresponding uncertainty in the category, because the category boundaries are only $10 \%$ apart from each other. Furthermore, the gategory B can also be reasonable for the occupants, because a human thermal sensation is an individual matter. Altogether, the measured results reveal quite a low air speed and draft risk levels and the most of locations had the draft risk below $10 \%$ at the usual heat gain level.

The relative locations of supply air diffusers, radiant panels and heat sources, as well as their interaction with each other, could be enhanced by a good design and an investigation on thermal environment including indoor airflow measurements and assessment on local draft risk levels in stable and dynamic conditions. In this way, the A gategory indoor environments can be reached. In the future, the radiant systems are likely an increasing trend when reducing the draft risk levels in office environments, e.g. the diffuse ceiling ventilation and the radiant panels can be combined. Alternative choice could be a displacement ventilation system, in which the low-velocity supply airflow generates the horizontal air layers in the occupied zone and the panels can then be located above the workstations (Hodder et al. 1998; Skistad et al. 2002). The advanced systems can also be combined with the personalized ventilation systems to improve microenvironments around workstations, in which the individualized control and knowledge on airflow interactions are desired matters while improving healthiness, thermal comfort and reducing energy use (Melikov 2004; Lipczynska et al. 2015; Melikov 2016; Xu et al. 2018). However, there are large individual differences between people with regard to the thermal preferences. Thus, an individualized control for a personalized ventilation or a radiant panel systems is recommended (Jaakkola et al. 1991; Melikov 2004; Melikov et al. 2013a; Luo et al. 2018). 


\section{Conclusions}

This study compares advanced cooling systems of indoor climate on indoor air thermal conditions and draft discomfort:

- None of the studied systems achieved the desired thermal environment of category A defined by EN ISO 7730. However, all the systems can fulfill the demands of category B except the CB system which falls to category $\mathrm{C}$ at the peak load conditions by exceeding the draft risk limit in one location.

- The studied systems provided mainly the acceptable draft risk level below $20 \%$ in thermal environment according to ASHRAE 55.

- The horizontal air temperature difference between the perimeter area and the corridor side was largest with the CCMV system and smallest with the DCV system at the both heat gain levels.

- The CCMV system provided the smallest share of locations, in which the draft risk level was higher than $10 \%$. However, the differences decreased between the studied systems while the heat gain was increased to the peak load level.

- The maximum of draft risks and the maximum of mean air speeds were smallest with the CCMV system in the both heat gain conditions.

- The study suggest to use radiant cooling systems combined with an air distribution sytem to decrease draft discomfort caused by free and forced convection flows.

\section{Acknowledgement}

The authors wish to acknowledge Mr. Kalin Kostov, Dr. Zhecho Bolashikov and Mrs. Sona Kolencikova from the International Centre for Indoor Environment and Energy at the Technical University of Denmark and their co-authors, as well as Mr. Etienne Daviet from the Institute National des Sciences Appliquées in Lyon, France, for the contribution to the measurements. 


\section{Funding}

The study was funded by the Technology Agency of Finland (TEKES) in RYM-SHOK research program, the Foundation LVY sr and the Confederation of Finnish Construction Industries RT.

\section{References}

Arens, E., H. Zhang, and C. Huizenga. 2006. Partial-and whole-body thermal sensation and comfort-Part I: Uniform environmental conditions. Journal of thermal Biology, 31(1-2), 53-59.

ASHRAE. 2017. ANSI/ASHRAE Standard 55-2017, Thermal Environmental Conditions for Human Occupancy. Atlanta: American Society of Heating, Refrigerating and Air-conditioning Engineers, Inc.

Bolashikov, Z.D., L. Nygaard, S.C. Uth, A.K. Melikov, P. Mustakallio, R. Kosonen, and I. Aho. 2014. Human perception of indoor environment generated by chilled ceiling combined with mixing ventilation or localised chilled beam under cooling mode. In 13th SCANVAC International Conference on Air Distribution in Rooms.

Carrer, P., E. De Oliveira Fernandes, H. Santos, O. Hänninen, S. Kephalopoulos, and P. Wargocki. 2018. On the Development of Health-Based Ventilation Guidelines: Principles and Framework. Int. J. Environ. Res. Public Health 2018, 15, 1360.

CEN. 2001. European Standard EN ISO 7726:2001. Ergonomics of the thermal environment. Instruments for measuring physical quantities. Brussels, Belgium: CEN.

CEN. 2005. European Standard EN ISO 7730:2005. Ergonomics of the thermal environment - Analytical determination and interpretation of thermal comfort using calculation of the PMV and PPD indices and local thermal comfort criteria. European Standard EN ISO 7730:2005(E), 3rd edition, 2005-11-15, Geneva, Switzerland.

CEN. 2007. European Standard EN 15251:2007. Indoor environmental input parameters for design and assessment of energy performance of buildings addressing indoor air quality, thermal environment, lighting and acoustics. European Committee for Standardization, 2007-03-26, Brussels, Belgium.

Chen, H.J., B. Moshfegh, and M. Cehlin. 2013. Investigation on the flow and thermal behavior of impinging jet ventilation systems in an office with different heat loads. Building and Environment, 59, 127-144.

Corgnati, S.P., M. Perino, G.V. Fracastoro, and P.V. Nielsen. 2009. Experimental and numerical analysis of air and radiant cooling systems in offices. Building and Environment, 44(4), 801-806.

Duszyk, M., A. Melikov, R. Kosonen, and P. Mustakallio. 2011. Comparison of Temperature and Velocity Field in Rooms with Chilled Beams and Radiant Panel Systems Combined with Mixing Ventilation. In Proceedings of Roomvent 2011 Conference, Trondheim, Norway.

Fan, J., C.A. Hviid, and H. Yang. 2013. Performance analysis of a new design of office diffuse ceiling ventilation system. Energy and Buildings, 59, 73-81.

Fang, L., D.P. Wyon, G. Clausen, and P.O. Fanger. 2004. Impact of indoor air temperature and humidity in an office on perceived air quality, SBS symptoms and performance. Indoor air, 14, 74-81.

Fanger, P.O. 1970. Thermal comfort. Analysis and applications in environmental engineering. Danish Technical Press, Copenhagen, Denmark, ISBN 8757103410.

Fanger, P.O., B.M. Ipsen, G. Langkilde, B.W. Olesen, N.K. Christensen, and S. Tanabe. 1985. Comfort limits for asymmetric thermal radiation. Energy and buildings, 8(3), 225-236.

Fanger, P.O., A.K. Melikov, H. Hanzawa, and J. Ring. 1988. Air turbulence and sensation of draft. Energy and buildings, 12(1), 21-39.

Fonseca Diaz, N., and C. Cuevas. 2011. Experimental study of the energy and thermal comfort performance of chilled ceiling panels. HVAC\&R Research, 17(3), 377-393.

Frontczak, M., and P. Wargocki. 2011. Literature survey on how different factors influence human comfort in indoor environments. Building and environment, 46(4), 922-937. 
Frontczak, M., S. Schiavon, J. Goins, E. Arens, H. Zhang, and P. Wargocki. 2012. Quantitative relationships between occupant satisfaction and satisfaction aspects of indoor environmental quality and building design. Indoor air, 22(2), 119-131.

Haverinen-Shaughnessy, U., D.J. Moschandreas, and R.J. Shaughnessy. 2011. Association between substandard classroom ventilation rates and students' academic achievement. Indoor air, 21(2), 121131.

Hodder, S.G., D.L. Loveday, K.C. Parsons, and A.H. Taki. 1998. Thermal comfort in chilled ceiling and displacement ventilation environments vertical radiant temperature asymmetry effects. Energy and Buildings, 27(2), 167-173.

Humphreys, M.A. 2005. Quantifying occupant comfort: are combined indices of the indoor environment practicable?. Building Research \& Information, 33(4), 317-325.

Jaakkola, J.J., L.M. Reinikainen, O.P. Heinonen, A. Majanen, and O. Seppänen. 1991. Indoor air quality requirements for healthy office buildings: recommendations based on an epidemiologic study. Environment International, 17(4), 371-378.

Jacobs, P., and B. Knoll. 2009. Diffuse ceiling ventilation for fresh classrooms. In 30th AIVC Conference Trends in High Performance Buildings, Berlin, Germany.

Jacobs, P., E.C. van Oeffelen, and B. Knoll. 2008. Diffuse ceiling ventilation, a new concept for healthy and productive classrooms. In Proceedings of Indoor Air, Paper ID: 3.

Jia, H., X. Pang, and P. Haves. 2018. Experimentally-determined characteristics of radiant systems for office buildings. Applied energy, 221, 41-54.

Karmann, C., S. Schiavon, and F. Bauman. 2017. Thermal comfort in buildings using radiant vs. all-air systems: A critical literature review. Building and Environment, 111, 123-131.

Kazanci, O.B., D. Khovalyg, T. Iida, Y. Uno, T.O. Ukiana, and B.W. Olesen. 2018. Experimental comparison of the thermal indoor environment created by a radiant, and a combined radiant and convective cooling system. In Roomvent\&Ventilation 2018.

Kitagawa, K., N. Komoda, H. Hayano, and S.I. Tanabe. 1999. Effect of humidity and small air movement on thermal comfort under a radiant cooling ceiling by subjective experiments. Energy and buildings, 30(2), $185-193$.

Kolarik, J., J. Toftum, and B.W. Olesen. 2015. Operative temperature drifts and occupant satisfaction with thermal environment in three office buildings using radiant heating/cooling system. In Healthy Buildings Europe 2015.

Koskela, H., H. Häggblom, R. Kosonen, and M. Ruponen. 2010. Air distribution in office environment with asymmetric workstation layout using chilled beams. Building and Environment, 45(9), 1923-1931.

Koskela, H., H. Häggblom, R. Kosonen, and M. Ruponen. 2012. Flow pattern and thermal comfort in office environment with active chilled beams. HVAC\&R Research, 18(4), 723-736.

Kosonen, R., M. Ahola, K. Villberg, and T. Takki. 2011. Perceived IEQ conditions: why the actual percentage of dissatisfied persons is higher than standards in-dicate? In: Abdul-Wahab S.A. (ed): Sick Building Syndrome. Springer Berlin Heidelberg, 2011, pp. 75-88.

Kosonen, R., P. Mustakallio, A. Melikov, and M. Duszyk. 2011. Comparison of the thermal environment in rooms with chilled beam and radiant panel systems. In Proceedings of Roomvent 2011 Conference, Trondheim, Norway.

Kosonen, R., P. Saarinen, H. Koskela, and A. Hole. 2010. Impact of heat load location and strength on air flow pattern with a passive chilled beam system. Energy and Buildings, 42(1), 34-42.

Kosonen, R., and F. Tan. 2004. Assessment of productivity loss in air-conditioned buildings using PMV index. Energy and Buildings, 36(10), 987-993.

Kosonen, R., and F. Tan, (2005). A feasibility study of a ventilated beam system in the hot and humid climate: a case-study approach. Building and environment, 40(9), 1164-1173.

Kristensen, M.H., J.S. Jensen, and P.K. Heiselberg. 2017. Field study evaluation of diffuse ceiling ventilation in classroom during real operating conditions. Energy and Buildings, 138, 26-34.

Lan, L., P. Wargocki, D.P. Wyon, and Z. Lian. 2011. Effects of thermal discomfort in an office on perceived air quality, SBS symptoms, physiological responses, and human performance. Indoor air, 21(5), 376390.

Le Dréau, J., and P. Heiselberg. 2014. Sensitivity analysis of the thermal performance of radiant and convective terminals for cooling buildings. Energy and Buildings, 82, 482-491. 
Lestinen, S., S. Kilpeläinen, R. Kosonen, J. Jokisalo, and H. Koskela. 2018b. Experimental study on airflow characteristics with asymmetrical heat load distribution and low-momentum diffuse ceiling ventilation. Building and Environment, Volume 134, Pages 168-180.

Lestinen, S., S. Kilpeläinen, R. Kosonen, J. Jokisalo, H. Koskela, A. Li, and G. Cao. 2019. Indoor airflow interactions with symmetric and asymmetric heat load distributions under diffuse ceiling ventilation. Science and Technology for the Built Environment, 25:6, 716-731.

Lestinen, S., S. Kilpeläinen, R. Kosonen, J. Jokisalo, H. Koskela, and A. Melikov. 2018a. Flow characteristics in occupied zone - An experimental study with symmetrically located thermal plumes and lowmomentum diffuse ceiling air distribution. Building and Environment, Volume 128, Pages 77-88.

Lin, Z., T.T. Chow, C.F. Tsang, K.F. Fong, and L.S. Chan. 2006. Effects of headroom on the performance of the displacement ventilation system. Indoor and Built Environment, 15(4), 333-346.

Lin, Z., T.T. Chow, C.F. Tsang, K.F. Fong, L.S. Chan, W.S. Shum, and L. Tsai. 2009. Effect of internal partitions on the performance of under floor air supply ventilation in a typical office environment. Building and Environment, 44(3), 534-545.

Lipczynska, A., J. Kaczmarczyk, and A.K. Melikov. 2015. Thermal environment and air quality in office with personalized ventilation combined with chilled ceiling. Building and Environment, 92, 603-614.

Luo, M., E. Arens, H. Zhang, A. Ghahramani, and Z. Wang. 2018. Thermal comfort evaluated for combinations of energy-efficient personal heating and cooling devices. Building and Environment, 143, 206-216.

Maula, H., V. Hongisto, V. Naatula, A. Haapakangas, and H. Koskela. 2017. The effect of low ventilation rate with elevated bioeffluent concentration on work performance, perceived indoor air quality, and health symptoms. Indoor air, 27(6), 1141-1153.

Melikov, A.K. (2004). Personalized ventilation. Indoor Air, 14(s7), 157-167.

Melikov, A.K. 2016. Advanced air distribution: Improving health and comfort while reducing energy use. Indoor air, 26(1), 112-124.

Melikov, A.K., R. Cermak, and M. Majer. 2002. Personalized ventilation: evaluation of different air terminal devices. Energy and buildings, 34(8), 829-836.

Melikov, A.K., and J. Kaczmarczyk. 2012. Air movement and perceived air quality. Building and Environment, 47, pp. 400-409. DOI:10.1016/j.buildenv.2011.06.017.

Melikov, A.K., B. Krejcirikova, J. Kaczmarczyk, M. Duszyk, and T. Sakoi. 2013b. Human response to local convective and radiant cooling in a warm environment. HVAC\&R Research, 19(8), 1023-1032.

Melikov, A., G. Pitchurov, K. Naydenov, and G. Langkilde. 2005. Field study on occupant comfort and the office thermal environment in rooms with displacement ventilation. Indoor air, 15(3), 205-214.

Melikov, A.K., Z. Popiolek, M.C.G. Silva, I. Care, and T. Sefker. 2007b. Accuracy limitations for lowvelocity measurements and draft assessment in rooms. HVAC\&R Research, 13(6), 971-986.

Melikov, A.K., M.A. Skwarczynski, J. Kaczmarczyk, and J. Zabecky. 2013a. Use of personalized ventilation for improving health, comfort, and performance at high room temperature and humidity. Indoor Air, 23(3), 250-263.

Melikov, A., B. Yordanova, L. Bozkhov, V. Zboril, and R. Kosonen. 2007a. Impact of the airflow interaction on occupants' thermal comfort in rooms with active chilled beams. In The 6th International Conference on Indoor Air Quality, Ventilation and Energy Conservation in Buildings.

Müller, D., C. Kandzia, R. Kosonen, A.K. Melikov, and P.V. Nielsen. 2013. Mixing Ventilation. Guide on mixing air distribution design. Federation of European Heating and Air-Conditioning Associations, REHVA, ISBN 978-2-930521-11-4.

Mundt, E., M.H. Mathisen, P.V. Nielsen, and A. Moser. 2004. Ventilation effectiveness. REHVA Guidebook no. 2, Federation of European Heating and Air-conditioning Associations.

Murakami, K., N. Kumano, S. Ikeda, H. Morita, and Y. Arai. 2015. Basic Study On Air-Conditioning System Using Passive Chilled Beams And Perforated Ceiling Panels. ASHRAE Transactions, 121, 1AA.

Mustakallio, P., Z. Bolashikov, K. Kostov, A. Melikov, and R. Kosonen. (2013). Thermal Conditions in a Simulated Office Environment with Convective and Radiant Cooling Systems. In Proceedings of 11th REHVA World Congress and the 8th International Conference on Indoor Air Quality, Ventilation and Energy Conservation in Buildings [Paper ID: 319]. 
Mustakallio, P., Z. Bolashikov, K. Kostov, A. Melikov, and R. Kosonen. 2016. Thermal environment in simulated offices with convective and radiant cooling systems under cooling (summer) mode of operation. Building and Environment, 100, 82-91.

Mustakallio, P., Z. Bolashikov, L. Rezgals, A. Lipczynska, A. Melikov, and R. Kosonen. 2017a. Thermal environment in a simulated double office room with convective and radiant cooling systems. Building and Environment, 123, 88-100.

Mustakallio, P., R. Kosonen, and A. Melikov. 2017b. The effects of mixing air distribution and heat load arrangement on the performance of ceiling radiant panels under cooling mode of operation. Science and Technology for the Built Environment, 23(7), 1090-1104.

Nam, D., and Z. Zhai. 2019. Experimental study on energy performance of active chilled beam systems. Science and Technology for the Built Environment, 1-11.

Nielsen, P.V. 2011. The "Family Tree" of Air Distribution Systems. In Roomvent 2011. TAPIR Akademisk Forlag. ISBN 978-82-519-2812-0.

Nielsen, P.V., R.W. Vilsbøll, L. Liu, and R.L. Jensen. 2015. Diffuse ceiling ventilation and the influence of room height and heat load distribution. Proceedings of Healthy Buildings Europe.

Nielsen, P.V., R.W. Vilsbøll, L. Liu, and R.L. Jensen. 2017. Diffuse Ceiling Ventilation, Load Distribution and Ceiling Design. Proceedings of Healthy Buildings Europe, Lublin, Poland. Paper ID: 0026.

Novoselac, A., and J. Srebric. 2002. A critical review on the performance and design of combined cooled ceiling and displacement ventilation systems. Energy and buildings, 34(5), 497-509.

Rahnama, S., P.V. Nielsen, A. Afshari, N.C. Bergsøe, H. Johra, and R.L. Jensen. 2019. Evaluating the cooling capacity of diffuse ceiling ventilation system-Full-scale experimental study. In E3S Web of Conferences (Vol. 111).

Rhee, K.N., and K.W. Kim. 2015. A 50 year review of basic and applied research in radiant heating and cooling systems for the built environment. Building and Environment, 91, 166-190.

Rhee, K.N., B.W. Olesen, and K.W. Kim. 2017. Ten questions about radiant heating and cooling systems. Building and Environment, 112, 367-381.

Saber, E.M., K.W. Tham, and H. Leibundgut. 2016. A review of high temperature cooling systems in tropical buildings. Building and Environment, 96, 237-249.

Sandberg, M., A. Kabanshi, and H. Wigö. 2019. Is building ventilation a process of diluting contaminants or delivering clean air?. Indoor and Built Environment. doi: 10.1177/1420326X19837340

Schiavon, S., F. Bauman, B. Tully, and J. Rimmer. 2012. Room air stratification in combined chilled ceiling and displacement ventilation systems. HVAC\&R Research, 18(1-2), 147-159.

Schiavon, S., F.S. Bauman, B. Tully, and J. Rimmer. 2015. Chilled ceiling and displacement ventilation system: Laboratory study with high cooling load. Science and Technology for the Built Environment, 21(7), 944-956.

Seppänen, O.A., W.J. Fisk, and M.J. Mendell. 1999. Association of ventilation rates and CO2 concentrations with health and other responses in commercial and institutional buildings. Indoor air, 9(4), 226-252.

Shin, M.S., K.N. Rhee, S.H. Park, M.S. Yeo, and K.W. Kim. 2019. Enhancement of cooling capacity through open-type installation of cooling radiant ceiling panel systems. Building and Environment, 148, 417432.

Skistad, H., E. Mundt, P.V. Nielsen, K. Hagström, and J. Railio. 2002. Displacement ventilation in nonindustrial premises. Guidebook no 1. REHVA.

Taleghani, M., Tenpierik, M., Kurvers, S., \& Van Den Dobbelsteen, A. (2013). A review into thermal comfort in buildings. Renewable and Sustainable Energy Reviews, 26, 201-215.

Tian, Z., X. Yin, Y. Ding, and C. Zhang. 2012. Research on the actual cooling performance of ceiling radiant panel. Energy and Buildings, 47, 636-642.

True, J., V. Zboril, R. Kosonen, and A. Melikov. 2007. Consideration for minimising draft discomfort in Rooms with Active Chilled Beams. In Proceedings of Clima, Wellbeing Indoors.

Wargocki, P., J. Sundell, W. Bischof, G. Brundrett, P.O. Fanger, F. Gyntelberg, S.O. Hanssen, P. Harrison, A. Pickering, O. Seppänen, and P. Wouters. 2002. Ventilation and health in non-industrial indoor environments: report from a European Multidisciplinary Scientific Consensus Meeting (EUROVEN). Indoor air, 12(2), 113-128. 
Wargocki, P., and D.P. Wyon. 2007. The effects of moderately raised classroom temperatures and classroom ventilation rate on the performance of schoolwork by children (RP-1257). HVAC\&R Research, 13(2), 193-220.

Woollett, J., and J. Rimmer. 2015. Active and Passive Beam Application Design Guide. Joint publication of REHVA and ASHRAE. ISBN 978-2-930521-14-5.

Wu, B., W. Cai, and K. Ji. 2018a. Heat source effects on thermal comfort for active chilled beam systems. Building and Environment, 141, 91-102.

Wu, W., N. Yoon, Z. Tong, Y. Chen, Y. Lv, T. Ærenlund, and J. Benner. 2018b. Diffuse ceiling ventilation for buildings: a review of fundamental theories and research methodologies. Journal of cleaner production 211 (2019), 1600-1619.

Wu, X., J. Gao, H. Wang, F. Wang, and Z. Tian. 2019. Impact of chilled ceiling in a high sensible cooling load room with underfloor air distribution. Science and Technology for the Built Environment, 25(6), 705-715.

Xu, C., P.V. Nielsen, L. Liu, R.L. Jensen, and G. Gong. 2018. Impacts of airflow interactions with thermal boundary layer on performance of personalized ventilation. Building and Environment, 135, 31-41.

Yang, B., A.K. Melikov, A. Kabanshi, C. Zhang, F.S. Bauman, G. Cao, H. Awbi, H. Wigö, J. Niu, K.W.D. Cheong, K.W. Tham, M. Sandberg, P.V. Nielsen, R. Kosonen, R. Yao, S. Kato, S.C. Sekhar, S. Schiavon, T. Karimipanah, X. Li, and Z. Lin. 2019. A review of advanced air distribution methodstheory, practice, limitations and solutions. Energy and Buildings 202 (2019) 109359.

Zagreus, L., C. Huizenga, E. Arens, and D. Lehrer. 2004. Listening to the occupants: a Web-based indoor environmental quality survey. Indoor Air, 14 (Suppl 8), 65-74.

Zhang, C., P.K. Heiselberg, Q. Chen, and M. Pomianowski. 2017. Numerical analysis of diffuse ceiling ventilation and its integration with a radiant ceiling system. In Building Simulation (Vol. 10, No. 2, pp. 203-218). Tsinghua University Press.

Zhang, C., P. Heiselberg, and P.V. Nielsen. 2014. Diffuse Ceiling Ventilation-A Review. International Journal of Ventilation, 13(1), 49-63.

Zhang, C., M.H. Kristensen, J.S. Jensen, P.K. Heiselberg, R.L. Jensen, and M. Pomianowski. 2016. Parametrical analysis on the diffuse ceiling ventilation by experimental and numerical studies. Energy and Buildings, 111, 87-97.

Zukowska, D., A. Melikov, and Z. Popiolek. 2012. Impact of geometry of a sedentary occupant simulator on the generated thermal plume: experimental investigation, HVAC\&R Research, 18(4), 795-811. 